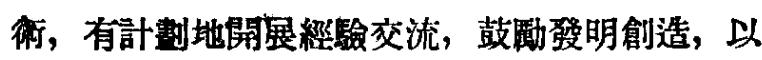
配合紡樴工業磪展的要求。

大會期間，代表們還聽取了上海地區開展會 務工作的經驗介紹和各地區的工作营報。上海地 剾的會務工作，在最初兩年由於始終停留在整理 組織、建立組織和辡固組織的階段上，没有很好地 結合學術研究等業務工作, 因此會員們普遍對會 務不開心，學會也因篇得不到會員的關心和支持 搞不出什㦄工作。直到1953年 3 月間, 負責會教工 作的理事們兽重研究了開展今後工作的問題, 明 確了專門學會結合學術研究工作的重姴性, 工作 才有了㙷著的改進。他椚出版了“紡織學會通訊”; 藇辦了學術筴座; 先後成立了清花、梳棉、悠粗、 精紀、準備、棉織、試驗等 7 個專業的 9 個小組， 進行學術討論; 組織參萑, 吸收先進的操作過程 和技術經驗，亚考察位良的工廠設诸; 協助生産
部門，設立聯合初級業餘紡織學校; 設立了專業 俄文閔詇速成理; 此外還粗樴會員參加各種重大 的社會活動。這些工作對於提高會員技術水平和 工作啨極性, 加强會員與拔術工人之間的聯系與 團結以及摭大學會的影響等，都起了一定的作 用，取得了一定的成績。上海地蛋工作經驗介絽 給各地代表以很大的幫助。

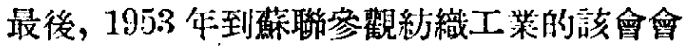

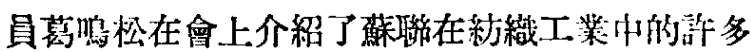
重要改進。大會還邀請蘇聯專家卡薙斯基仁了“關 於蘇聯紡織技術領域的重大成就與䋓織僘的改造 問題”的專題報告, 使到會代表進一步朋確了絖織 工業技術發展的方向和遠景。

大會並通過了“中國紡織工程學會章桯”，選 出了第一屆全國理事會理事。

\section{（本 刊）}

\title{
中央地質部召開有色金屬專業會議
}

有色金虽碈産是冶金工業的重要原料, 在重 工業建設中，有色金屬佔着非常重要的地位。

第一個五年計劃建設開始後，中夾地賢部於

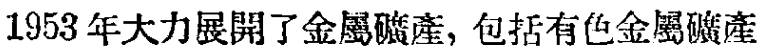
的勘探工作，獲得了很大成績。一年乘，經過了 有限的普查和局部的勘探，對葉些新型有價佔的 睡床也有了新的認識與初步評價，篇今年的勘探 工作打下了很好的基稳。但總的說來，地筫勘探 工作還不能全面地滿足國家經济建设的當前需要 和將來的要求。目前, 地犋工作上的薄弱環節, 不僅表現在然料資源的勘探方面，而且在有色金 屬資源芴探方面，特别是某些需要量不大但篇冶 金工業所必需的酸産資源方面，還不能滿足國家 的要求。

今年有色金風資源的炡探在全部地質散探工 作中佔着相當重要的位置。今年的任预是E大的， 撂探項目比去年加多了，酸量要求方面也此去年

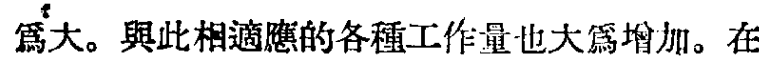
重點勘探的同時，還要卧開大規模普企工作，篇

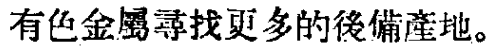

今年的任肦是鞑巨而光柴的。地翼工作者們 必須如期完成或提前完成計劃要求, 以保登有出

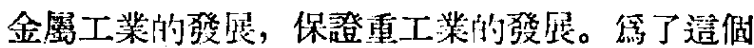
目的，中央地啠部在 1954 年2月 15-27 日召阙

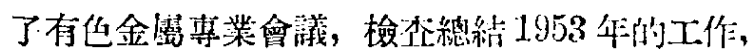
研究喐置今年的工作，進行一次有系統的有色金

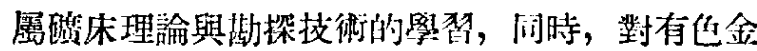
䐂的勘探透景作一次此較光分的研究與敦論, 以 便進一步提淌今後的勘探工作。

出席這次會潼的有中尖地資部及各地算局的

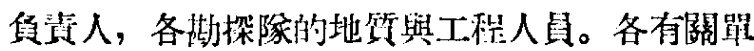

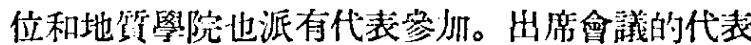
共二百餘人。

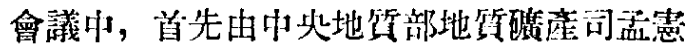

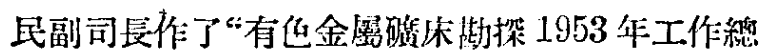
結及 1954 年的任吩”的赫少。他在岗定了 1953 年的工作成績之後, 提出了勘探工作中的經驗及 存在問題。在磪床評價方面, 他指出, 由於工作

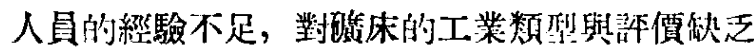

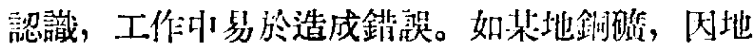


質工作做得不够，不了解磷床類型，而幾乎被放 栾, 後經蘇聯專家及時指正, 認篇極有前途, 因 而又重新獲得重就, 僅在短期的工作之後, 就初 步確定了融础床的遠大前途。因此，地犋工作人 員必須在理論聯系實際的基砵上, 認真學習蘇聯

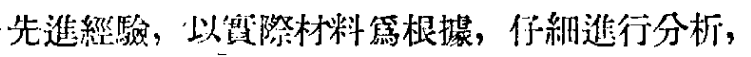
以期能更好地作好碳床呠價，用來指導墈探工作。

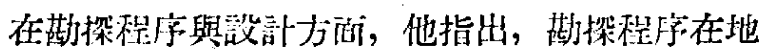

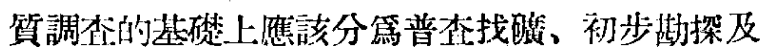
詳細撕探三個階段, 這是保登在垠經流最迅迎的 條件下, 探明碳床情况, 求得媎量的必要步驟。 在 1953 年有色金屬酸麻的地翼勘探工作中, 在蘇 聯專家䈉助下, 已開始按照工作程序進行工作, 但部分地煰仍有荎頭並進、超越程序的情况弡生。 如有的勘探榢在没有拝督地表情况以前, 就開始 了鑽探及硐探，而且不問余:一募探階段的目的， 齊頭並進，結果由於勘探方法錯誤，做了幾個月 的工作, 還提不出碳床的初步評價。在設計工作 上, 主要的缺點是缺乏具有全套圖表 的設計文 件, 對水交地望及探樣設計不够重視。有的䒨探

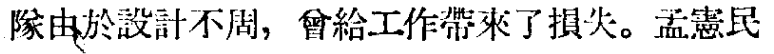
在報告中也指出了在地質測鼠一榑探、淺州探、 鑽探、採樣、化驗、水文地質等技術問題方泊门, 以及在綜合聯系與材料緛錄方面存在的一些阔 題。

會㼁中, 用了兩灭的時間, 由七個墈探榢作

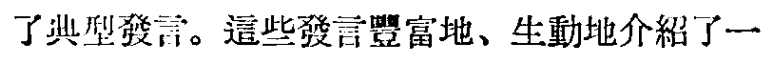
年來的工作情况與成就、工作經驗與體會。

從發言中清楚地看出，有色金屬募探工作有 着骎足的進是, 工作中積累了不少經驗, 取得了

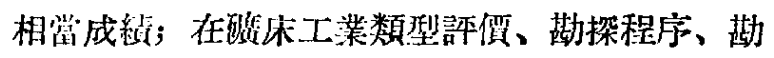

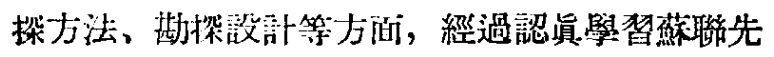
進經驗和筫徽蘇聯䂧家建議以後, 都有了詐多新 的認識㦼提漓, 大大推動了工作的進展。正如蘇 聨專家雅吉諾大在談到對會議的感想時所說: 這 次會議上，问志們已能提出上較深入、更接近於 篇解决㴭際閔題所需解决的問題。

接受了戠年的絁驗敉訓，學替了蘇聯的先進 䋑驗以後, 大家已經從工作中認識到撕探一個酸 休以前, 必須首先確定磞床的工業類型, 根據不 同工業類型子可以確定適當的勘探方法 然後再 根臁具體情况作出壦探設計與工作計劃。祇有這
樣，扣可以成功地得到預期的成果。

從一年的工作中, 地筫工作者也蕉一步體會 到蘇聯先進地筫工作經驗的正確性, 大大提高了 學㫘蘇聯的熱情。從 1953 年所有工作成績中㙷 示出, 没有蘇聯先進理論與技術的指綮, 没有蘇 “聯專芜的無私繁助, 是不能取得這樣成績的。

蘇聯地質手家羅吉榙夫在會議中作了“有關

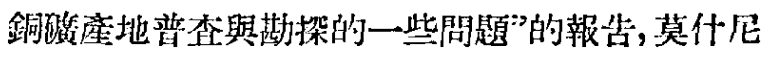
柯夫作了“鉛鋅喽的普查及愺探方法”的報告, 他 們在報告中都詳細地叙述了有關碳床的工業類型 及其相應的普查與助探方法。解聯水文地質專家 馬舒柯夫作了“水文地質調查和水源 莇 查的基本 方法”的報告。顧功叙作了“地球物理㯕探方法使 用在有色金屬础的目前情况和今後方向”的報告。 出席的代表們結合筫際工作體驗, 對這些報告都 淮行了學習與討論, 在䒨探理論與技術上又得到 淮一步的提高。

篇了正確認識我國有色金屬饭的勘探速景, 以便有效地洒㯰今後的勘探工作, 會上, 中央地筫

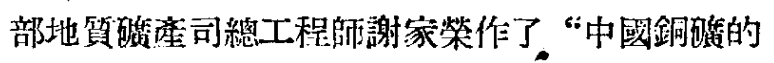
愺探遠景” 的報告。報告中叙述了我國䦌探銅础 的悠久歷史, 並依據自然地理與地供佟作主张把

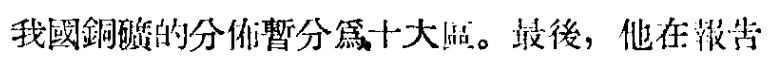
中捉出与今後莇探方向, 並肯定地說, 我國大地

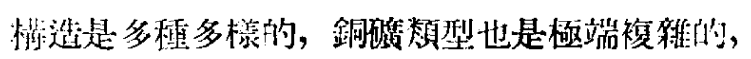

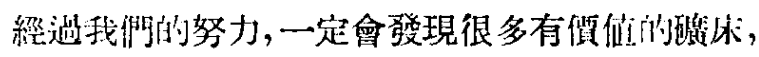

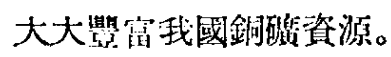

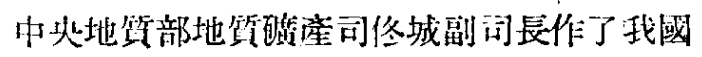

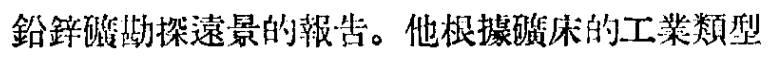

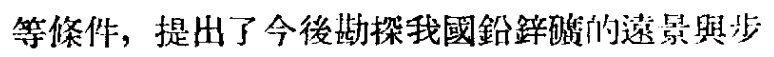
驟。

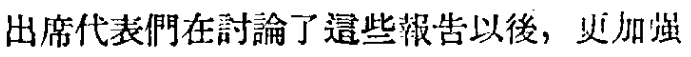

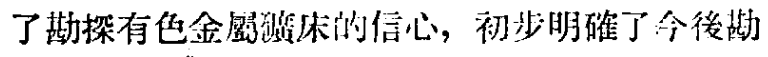
探的主要方向。會議中，對今年有色金慮椥探没 計作了審查與確定, 詳細部署了今年的工作。

中央地質部宋應副部長在會議總絬中, 進一 步指出地質工作者們必須認㫐注意础休的工業類 型、勘探程序與方法, 遭是䒨探工作中最重要與 最基本的問題。他詳細分析了 “完成任務” 的標 蕉, 並指出今後要努力提高設計工作望量, 注意 工作中探㮈、化驗、資料量緾等工作, 今後也要 注意認题執行報告與聯系制度。最後, 他號召斿 


\section{中國科學院研究人員皘極認道學䀤 \\ 國家過渡時期緦路䌭}

中國科鼠院在京的各研究所和各行政單位的 科學工作人員，自 1953 年11月16日起, 即開展了 關於國家過渡時期總路綫的學晳。這一學㕷的目 的首先是要求大家全面地系統地學晳總路就，領 會其精神實質，並在逭基礎上,聯系工作和思想， 提高思想水本, 改進科學業務工作。一般科學工 作人員對這次學習都很重視, 符多研究所的所長 都親自動員扸置了學習。在學習過程中, 大家都 以很高的熱情聽取了有關總路綕的許多專題 報 告, 認道地閱讀了中國共産黨中央宣傳部製發的 “關於黨在過渡時期總路䋐的學替和宣傳提綱”以 及其他許多重要的寥考文獻, 並展開了熱烈的討 論。到今年 2 月底, 各單位科學工作人員都全面 地系統地學晳了總路綫的基本內容, 初步領會了 總路綫的精神實質, 獲得了顯著的成績。

通過前一階段的學各, 中國科學院的科學工 作人員首先從理論上明確了以下浇個重要問題, 這就是: 中國革命兩個階段的性質、任教及其相 吕聯系，我國從新民主主義社會到社會主義施會 的過渡時期的特點及必要性，過渡時期總路綫的 '實質，國家社會主義工業化的意義及其與國家對 農業、手工業與私營工商業的到會主義改造的關 係, 農業、手工和私營工商業融會主義改造的 :具體道路以及工農聯盟的重要意義等; 並對各種

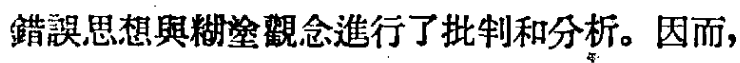
普遍地提高了政治理論水平,擴大了自己的哏界。

由於瞭解了我國社會的現實情况, 瞭解了黨 領導我國人民走向社會主義的具體道路, 科學工 作人員從而更進一步地提高了愛國主義覺悟和工 作皘㥛性。有的科學家猃, 學習了總路綫, 進一 步體會到馬克思列寧主義和黨的政策的偉大和正 倠, 和毛主席領導的英明。有的科學家詮, 過去 總感到我國工業落後, 比不上資本主義國家, 現 在知通我們只要桱過伐五年計劃, 就可以成篇
先進的社會主義的工業農業國家, 想起来真感到 十分興舊, 篇我們偉大的跙國而䮡敖。許多科學 家都表示要更好地做好自己的崗位工作, 爭取建 設社會主義社會的勝利早日到來。也有不少科學 工作者表示, 要更加努力學習馬克思列夏主義, 樹立集體主義思想。

通過總路綫的學替，對科學院的工作方向有 了進一步的體會。大家都進一步認識到科學院的 大量工作，應該服從人民的迫切的需要，國家當 前的任陊、國家建设計劃的任狋。具體地表現在 許多研究所在擬訂 1954 年的科學研究工作部劃 時, 都能夏好地從國家的迫切需要出發, 乘安排 自己的工作。例如, 古生物研究所的研究人員表 示要更好地配合地資工作需要, 来進行工作。植 物研究所、地理研究所的許多高級政究人員, 都積 極參加了有關黃河開發的研究工作。品业是研究所 的研究人員也表示要第了配合湖國的林業梢糧增

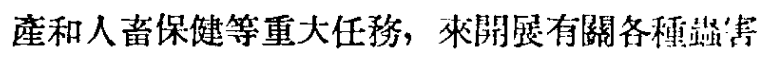
的研究。因而, 各研究所所訂的1954年工作补啮, 比1953年的計劃一般都有了顯著的進步。此外, 在野行節約方酒, 許多單位也有了具體的表現, 在購置利用儀器方面都比以前注意到精打細贸。

篇了繼續哚入總路綫的學晳，篇了進一步使 總路綫的精神和科學研究業務具體結合起來, 中 國科學院學委會對第二階段的學柏，在三月初， 叉作了全面的倠㯰。下一階段的學晳要求大家在 總路綖學習的基礎上全面地聯系工作筫際和思想 實際。要求大家通過學習，能在總路縋烚溚的照 燿下，明確科學工作在過渡時期的地位和作用， 發現倜人或單位工作中的缺點, 並提出如何改進 工作的辦法, 使每一個科學研究工作者和科學行 政工作者的業移水平和思想水平都能有所提高, 將總路的精神具體地貫徹到工作中去, 彼此友 愛團結合作，允分發墠漂在力量，提高理論水平 